\title{
The Longue durée of Brexit
}

\author{
Politics, Literature and the British Past
}

\author{
Daniel Carey
}

\begin{abstract}
The complex proposition posed by Brexit challenges us to reinvestigate British reflections on identity from an historical point of view. This contribution considers a range of precedents, beginning with the English Reformation before considering questions of sovereignty, separation, immigration and exceptionalism in the seventeenth and eighteenth centuries. The claim is not that history straightforwardly facilitates an understanding of the fissures associated with Brexit, but rather that the present is ironised as much as it is explained by the past. We have much to learn not just from history but from works of poetry, fiction and drama that engage with historical concerns of identity and politics. The contribution looks first at Defoe's poem The True-Born Englishman (1701) and aspects of Robinson Crusoe (1719), with their mixed-conceptions of identity, followed by attention to Shakespeare's Richard II, Henry $v$, and the plot twists of Cymbeline, a romance predicated on separation from Roman authority. The contribution concludes with Churchill and the contradictions in British attitudes to Europe inherited by Theresa May and Boris Johnson, which promise to endure as the UK redefines its relationship to Ireland and Continental Europe.
\end{abstract}

The outcome of the UK referendum on whether to leave or remain in the European Union has dominated politics in parliament and the country since the result of the vote was announced on the morning of the 24th of June 2016. The narrow margin of victory for the leave campaign (51.9\%), the fact that two of the four constituent parts of the UK voted by majority to remain (Scotland and Northern Ireland), the overwhelming desire to stay in the EU registered across London (the dominant base of the population and economic centre of power) have ensured that the deep divisions apparent in the campaign have not disappeared. Indeed they are set to continue, not least because it is unclear what exactly people intended to vote for (contradicting Theresa May's slogan 'Brexit means Brexit'), and whether political will can be permanently vested in such a transitory act. The resulting free-for-all of interpretation and struggles over a second referendum or 'people's vote' on the outcome of negotiations

(C) DANIEL CAREY, 2021 | DOI:10.1163/9789004436107_005

This is an open access chapter distributed under the terms of the CC BY-NC-ND 4.0 license. 
testify to this confused scenario. The stakes are so high because the vote did not, as in a general election, establish a government of a certain duration, but undid an entire set of longstanding relationships, while provoking anxious and unresolved issues of identity that will continue to confront the country for a generation or more.

The question that Brexit poses is at one level political but it remains, ultimately, a conflict over identity. The identity problem in this context has two related strands - the internal dimension of how the future will play out for the component parts that make up an ostensibly United Kingdom, and the external dimension as the UK negotiates a future alongside but no longer within the EU. The two dilemmas converge, of course, on the island of Ireland, where the shared border provides the key point of contact. But the larger confrontation is with the UK's image of itself: is the narrative one of weakness or strength, reasserted sovereignty or isolation in an interconnected world?

This bewildering predicament has inevitably prompted a search for some perspective on these developments. This essay attempts to chart a longue durée of Brexit by considering historical precedent, returning initially to the English Reformation and religious difference before considering questions of sovereignty and the composition of the nation. The claim is not that the fissures associated with Brexit lend themselves to ready interpretation by mere recourse to history, but rather that the present is ironised as much as it is explained by the past. The search for analogy is therefore inspired by an attempt to gain perspective, not in order to simplify the current cataclysm or claim that it could have been readily predicted. We have much to learn not just from history but from works of poetry, fiction and drama of the same period that engage with historical concerns of identity and political form. Here I consider various texts by Shakespeare and Defoe, which provide us with a crucial resource since they remain attuned, above all, to historical contradictions.The urgency associated with Brexit has given fresh relevance to inquiries into the emergence of concepts of Britain and Britishness. ${ }^{1}$ Historians concerned with this matter have explored the conditions of state formation, asking where and when did a sense of national identity (and destiny) arise. Or was it merely a fiction imposed on a complex cultural topography, driven by political interests? Attempts have been made to wrest the narrative away from an English-centric

1 Fintan O'Toole maintains that "Brexit is essentially an English phenomenon" (2018, p. xvi) and accordingly he largely elides Scotland and Wales from his discussion, but a satisfactory account must take into consideration the whole of the UK, not least given the voting patterns which saw substantial numbers support the Leave campaign across the country (if not by a majority in Scotland and Northern Ireland). 
account in favour of greater attention to the archipelago's three kingdoms and the composite monarchy. The periodisation adopted in these analyses varies considerably. Some settle on the sixteenth century and the reign of Henry VIII as a decisive turn; others opt for the union of crowns under James VI and I; and others still emphasise the formal Act of Union in $1707 .{ }^{2}$ My discussion, inevitably selective in the primary sources it responds to, follows this pattern of seeking an early modern orientation on the dilemmas raised by reflection on Brexit. This is perhaps the longest of longues durées. ${ }^{3}$

Arguments in favour of Brexit have a complex genealogy, resonating in different ways with historical antecedents. In terms of epochal developments based on severing a longstanding relationship with extra-national entities, the break with Rome in the context of the English Reformation in the sixteenth century stands out for a number of reasons. ${ }^{4}$ This historical moment represents, under the guise of religious identity, a dispute over sovereignty. Conversely, the proBrexit position leads with sovereignty and the political while being underpinned, in many cases, by nationalist identity politics.

The resonances with the Reformation occur in conjunction with the ways in which the EU has continually been framed in public discourse as an external power branching across the Continent that requires but is resistant to reform. To change it from the inside as part of a process of negotiation remained an option, at least rhetorically, even for a Tory Prime Minister such as David Cameron. But his failure to achieve satisfactory results, along with the political momentum gained by the deeply Euro-sceptic wing of his party - strengthened by the polling success of UKIP and conservative defections - led him to succumb to pressure for a referendum. ${ }^{5}$ For the radical collective in favour of leaving, reform of

2 For accounts that begin in the Tudor period, see Bradshaw, Morrill (1996) and Bradshaw, Roberts (1998); for the era of James VI and I, see Mason (1994) and Kerrigan (2008). Mason (2004) complicates the picture between these two periods, describing Scottish interest in foregrounding an idea of Britain in the Tudor period; for the Act of Union, see Colley (1992) and Robertson (1995). For a study focusing on the early modern formation of English national identity, see Helgerson (1992).

3 See Black (2019) and Heuser (2019) for even earlier points of departure.

4 Cottret (2019) in his book on the Tudors describes this moment as "Un premier Brexit" (pp. 173-189).

5 See Shipman (2017) for a valuable account of the campaign. 
Europe was presented as an impossibility. Only the assertion of national sovereignty could overcome this enduring obstacle and reclaim politics.

The English Reformation represented the beginning of a long process of transformation with serious effects on international relations and the emergence, over time, of a new and distinctive identity. In the present moment, much will depend, inevitably, on the economic and political strength of the EU from which the UK extracts itself, and the capacity of a rechristened United Kingdom to forge alliances (and trading relationships) of its own. The UK will not be withdrawing from NATO any time soon, of course, so the alteredstates scenario has real limitations, whatever it may mean for laws and regulatory frameworks. In this respect it is instructive to consider that although the English Reformation led to the creation of an Established Church, the difference between its rites and those of Rome was minimal. The theology may have been rethought but church service and governance remained relatively unchanged. ${ }^{6}$ We may find in the case of Brexit an ideological transformation which affects very little of life on the ground. In fact, both historical instances of separation constitute assertions of power by a political elite, based on demonising an authority positioned as external. They may require and draw sustenance from popular discontent and widely-held perceptions of intransigence and wastefulness, but they depend on the organised and wellfinanced management from the top. The new regime the UK ends up with will entail a different administrative and legal structure, just as the ecclesiastical apparatus was substituted in the time of Henry viII. But ties with Europe will and must remain strong. The break in that sense will only ever be partial, an illusion as much as a reality.

The second point is perhaps more significant. The English Reformation left a divided country. Catholics - for our purposes we can call them 'remainers' - did not disappear as a voice or constituency, nor was the political nation suddenly eradicated of opponents and the country reassembled in ideological purity and consensus. The retaliation against Protestants by Mary I, who reigned from 1553 to 1558 , reinforced by her marriage to Philip of Spain in 1554, brought the durability of the English Reformation into question, but her short tenure gave way to Elizabeth I and a process of Protestant consolidation (her prospective Habsburg marriage alliances in particular would have complicated the position of course). This is a story of decades of efforts to deal with internal

6 The establishment of a national church engendered a fraught history of dealing with the fallout from Dissenters (and in Scotland with a Presbyterian national church). The pro-Brexit position is no more coherent in that respect and is likely to fragment after an agreement is reached. 
and external Catholic threats. ${ }^{7}$ In the seventeenth century a different struggle occurs in the context of the English Civil War over the form of the state and the role and power of the church, but the Restoration reinvigorated the threat of Catholicism once more. Only with the Glorious Revolution in 1688 is something like an enduring Protestant stamp placed on the country. I suspect that ensuing elections in the UK, leadership contests, and other political struggles will play out similar divides over Europe going forward. Partly this is due to the fact that the UK has no tradition of unity governments, favouring the winnertake-all model. (The recent experience of coalition under the Tories and Liberal Democrats did nothing to persuade the major parties that alliances of this kind were politically helpful, at least to the junior partner.)

The English Reformation was followed by an imperial moment associated with the Welsh Acts of Union of 1535 and 1542 and Henry VIII's assertive rule in Ireland. But control of Ireland was, to put it mildly, imperfect, and proved an ongoing source of difficulty, exacerbated by religious difference (where the Old English and New English parted company over allegiance to Rome or to the Anglican faith). Rebellion in Ireland in the sixteenth, seventeenth, and eighteenth centuries and beyond, was often hinged on (inadequate) support from Continental allies. From this perspective, the assertion of UK sovereignty made in the referendum remains tragically naive about the implications for Ireland, ${ }^{8}$ where the UK governs only the province of Ulster (reinforced by subsequent wrangling over the provision of an Irish backstop agreed in December 2017). The complex position is underscored by treaty commitments under the Good Friday Agreement and the Republic's position as a member state of the EU. Ireland's allies have in this new scenario proved, thus far, more resolute than in the past.

Sovereignty, Separation and Immigration

The desire for regained sovereignty lies at the heart of the Brexit aspiration for many of its supporters. Thus the great refrain has been to 'take back' control of laws and borders. ${ }^{9}$ The prospect of unencumbered legal control is bound up with the wish to gain freedom from the restraint of the European Court of

7 For a classic study, see Dickens (1989); for a revisionist account, see Haigh (1993); for a recent major study Marshall (2017); see also essays on the development of the English Reformation in MacCulloch (2016).

8 On this question, see Connelly (2018).

9 See Heuser (2019). For valuable reflections on sovereignty in the era of globalisation, see Sassen (1996) and (2008). 
Justice and the rule-making role of the European Commission and Parliament. At the same time, the sovereignty argument pays scant attention to the model of power sharing elaborated in regional assemblies and parliaments in the UK, and the whole history of sustained political effort and agitation that brought them into being. Scotland has scarcely figured in the discussion, despite the size of the vote there to remain, largely because its position raises no constitutional questions. The Good Friday Agreement, by contrast, commits the UK and Irish governments to forms of shared sovereignty, a situation made less conspicuous by occupying shared space under the umbrella of the EU. The Scottish government's attempt to insist on involvement in the decision over whether to trigger article 50 was swiftly rejected by the UK Supreme Court in January 2017.

Control of laws is one thing, but control of borders speaks to the desire to limit immigration, nullifying the principle of the free movement of peoples enshrined in the EU's concept of itself and one of the so-called Four Freedoms. This is not to say that other European states have not struggled with this prospect. Different analyses can be provided to explain the impulse in the UK, but a resurgent nativism is clearly part of the story (evident in the campaigning of UKIP for example). The conventional alignment of national identity with ethnicity across Europe (German, French, Spanish, Italian, etc.) deepens the problem. In this respect the UK has an advantage to the extent that the term 'Britain' is more inclusive, encompassing the kingdoms (even if it does not enfranchise Northern Ireland). ${ }^{10}$

The concept of the UK as a separate and sovereign entity, a rule giver not a rule taker, ignores the fact that England has been headed in the past by plenty of 'foreign' monarchs. The House of Hanover is perhaps the best-known example, given George I's reputation for speaking limited English, at least at the outset of his reign. But among foreign sovereigns it is also worth remembering William III (1650-1702), i.e. the Prince of Orange and Dutch Stadholder, victor in the Glorious Revolution. His marriage to James II's Protestant daughter, Mary, provided the basis for his intervention to claim the English crown and the invitation to form a joint monarchy in order to unseat James II. William ruled on his own after Mary's death in 1694, and his 'foreignness' became an object of attack for opponents. The complaints focused on his position on standing armies and his absence in Holland in the summer of 1698, after the

10 The official title of the country is the United Kingdom of Great Britain and Northern Ireland, hence the Democratic Unionist Party's annoyance over the country's branding in Olympic competitions as 'Team GB' (changing this to 'Team UK' was a manifesto pledge of their 2017 general election campaign). 
conclusion of the Nine Years' War, where he executed treaties without parliamentary authority and, a year later, doled out grants to friends for forfeited Irish lands. He was condemned in a verse attack under the title The Foreigners, particularly directed against William's favourites. This work famously provoked an anonymous response from Daniel Defoe in the form of The TrueBorn Englishman (1701).

Defoe's poem, pitched in a satirical vein, complicates the picture of the native and foreign to make a polemical point. ${ }^{11}$ Some of its arguments continue to resonate as a reply to the nativist understanding of 'British' or 'English' identity underpinning a certain strand of Brexit support.

The preface declares that the author is not Dutch, though some might suspect him of being so - rather he is English and he urges his countrymen to "behave themselves better to Strangers, and to Governors also".12 The significance of 1688 might be reinterpreted in this context not so much as the assertion of 'liberty' but rather as the renewed rejection of intrusion by a foreign power in the form of the Catholic Church and the papacy with the support of a Catholic monarch, even a legitimate one. Thus the preface complains that 'pretending' Protestants have in fact "all along endeavour'd to reduce the Liberties and Religion of this Nation into the Hands of King James and his Popish Powers". 13

But the theme for which the poem remains best known is its way of handling the 'identity problem' in contemporary politics. While meditating on English ingratitude towards William, Defoe considers the admixture of peoples that make up the category of the 'English', giving the lie to pronouncements about foreigners. Often invaded, England has found:
While ev'ry Nation that her Pow'rs reduc'd
Their Languages and Manners soon Infus'd.
From whose mixt Relicks our compounded Breed,
Making a Race uncertain and unev'n,
Deriv'd from all the Nations under Heav'n. ${ }^{14}$

He recites the arrival of the Romans with their mixed crew, followed by Jutes, Saxons, Danes, Scots, the Picts, the Irish and then the Normans. They "Blended with Britains, who before were here", resulting in that ultimate hyphenated

\footnotetext{
11 For a recent reading of the poem, see Borsing (2017), ch. 1.

12 [Defoe] (2003), p. 83.

13 [Defoe] (2003), p. 83.

14 [Defoe] (2003), pp. 89f. (ll.169-74).
} 
identity, "Your Roman-Saxon-Danish-Norman English". ${ }^{15}$ The Normans then transformed the country once again. Since that time the pattern has only accelerated:

Dutch, Walloons, Flemings, Irishmen, and Scots,

Vaudois and Valtolins, ${ }^{16}$ and Hugonots,

In good Queen Bess's Charitable Reign,

Suppli'd us with Three hundred thousand Men. ${ }^{17}$

The chronology is a little askew since the Huguenot emigration is a largely seventeenth-century phenomenon in the context of the Revocation of the Edict of Nantes (1685). But the point in general is well-made (although not one that that Nigel Farage has absorbed despite his Huguenot heritage). The important thing is the poem's emphasis on the fact that "from a Mixture of all Kinds began, / That Het'rogeneous Thing, An Englishman":

For Englishmen to boast of Generation,

Cancels their Knowledge, and lampoons the Nation.

A True-Born Englishman's a Contradiction,

In Speech an Irony, in Fact a Fiction. ${ }^{18}$

Defoe's Explanatory Preface to the ninth edition makes clear that he regarded this mixture as a national advantage, not a defect (indeed the Scots, Welsh and Irish suffer from being unmixed in his view). ${ }^{19}$ The poem's argument might be considered specific to a particular political occasion, but there is evidence elsewhere in Defoe's work of his interest in issues of identity and how they play out in a hybrid setting. His 1719 novel, Robinson Crusoe, is worth considering in this context. There is no more English and indeed resolutely Protestant character in the history of fiction than Crusoe (a point that James Joyce remarked on critically). ${ }^{20}$ Yet we are told at the outset of the book that Crusoe's

15 [Defoe] (2003), p. 9o (ll. 185, 194).

16 The Vaudois or Waldenses were a heretical group in Europe, especially Italy; the Valtolins were Protestants residing in Valtellina (Switzerland), who suffered a massacre by Catholics in 1620.

17 [Defoe] (2003), p. 92 (ll. 259-62).

18 [Defoe] (2003), pp. 94, 95 (ll. 334-5, 370-73).

19 [Defoe] (2003), p. 79. For a wider reading of the theme, see Schmidgen (2013).

20 Joyce commented in a lecture in March 1912 in Trieste: "All the Anglo-Saxon soul is in Crusoe: virile independence, unthinking cruelty, persistence, slow yet effective intelligence, sexual apathy, practical and well-balanced religiosity, calculating dourness." Joyce (2000), p. 174. 
father was "a foreigner of Bremen" who settled in Hull. The original surname was Kreutznaer, he tells us, "but by the usual Corruption of Words in England, we are now called, nay, we call our selves, and write our name, Crusoe". ${ }^{21}$ This aspect of the story is reasonably well remembered. On the deserted island, scene of his captivity, Crusoe seems intent above all on replicating an English way of life, rather than going native. In the midst of his isolation he advances in social standing, with a town house and a rural retreat, a bower and other appurtenances of an English lord or member of the gentry. Yet it is only at the end of the book that we learn from him some intriguing details about his time as young man in Brazil, following his escape from captivity in North Africa. There he established a tobacco plantation and - intending to shift to labour-intensive sugar production - he embarked on a mission to Africa to secure slaves. This fateful decision resulted in his shipwreck on the deserted Caribbean island where the main sequence of the novel occurs. After Crusoe's recovery from the island following a residence of twenty-eight years, his fortune is restored to him and he contemplates returning to Brazil, where, he tells us, he had been previously naturalised. What restrains him is his new religious sensibility - a Protestant identity cultivated during his years of isolation through reading the Bible, engaging in prayer and conversation with God, and his later evangelising of Friday. He notes that when he formerly lived in Brazil, he "had made no Scruple of being openly of the Religion of the Country, all the while I was among them". Now, however, Crusoe begins "to regret my having profess'd my self a Papist". ${ }^{22}$ Despite these reservations, he still decides to confer on the Priory of St. Augustine (which, over the course of his long absence, received a substantial portion of the proceeds from his plantation), ${ }^{23}$ a gift of 500 moidores for the monastery and 373 to the poor, "desiring the good Padres Prayers for me". 24

We can, in short, recover an alternative narrative in the most English of sources that suggests a history of hybrid identities, less hostile to the intermixing and integration suggested by the European project and rejected by some Brexit supporters.

\footnotetext{
21 Defoe (2007), p. 5 .

22 Defoe (2007), p. 241.

23 They use this for the "Benefit of the Poor, and for the Conversion of the Indians to the Catholick Faith". The king's third (of Crusoe's half), meanwhile, "was it seems granted away to some other Monastery, or Religious House". Defoe (2007), pp. 235, 236.

24 Defoe (2007), p. 242. It is evident that Crusoe's business partner is Catholic, since Crusoe reports that this individual said many "Ave Marias to thank the Blessed Virgin that I was alive" when he hears from him; Defoe (2007), p. 239.
} 
English or British exceptionalism - the sense that the country has a separate destiny, different from that of Europe - is deeply engrained. The Continent is an 'elsewhere' from which it is physically disconnected but also morally distinct. As Theresa May remarked in her speech in Florence on 22 September 2017: "perhaps because of our history and geography, the European Union never felt to us like an integral part of our national story in the way it does to so many elsewhere in Europe."25 The concept of the "sceptred isle", a place apart with a privileged role and history conferred by geography, derives of course from Shakespeare's Richard II. In his account of the attitudes of leading twentieth-century British political figures to Europe, Hugo Young remarks:

The mythology of the scepter'd isle, the demi-paradise, bit deep into the consciousness of many who addressed the question, beginning with Churchill himself. The sacredness of England, whether or not corrupted into Britain, became a quality setting it, in some minds, for ever apart from Europe. Tampering with this blessed plot was seen for decades as a kind of sacrilege which, even if the sophisticates among the political class could accept it, the people would never tolerate. ${ }^{26}$

The passage in the play is worth looking at with care. As with so many famous speeches in Shakespeare its inherited meaning - that is, the way it is popularly understood - differs from its meaning in context. ${ }^{27}$ Here are the lines:

This royal throne of kings, this sceptred isle,

This earth of majesty, this seat of Mars,

This other Eden, demi-paradise,

This fortress built by nature for herself

Against infection and the hand of war,

This happy breed of men, this little world,

This precious stone set in the silver sea,

Which serves it in the office of a wall,

Or as a moat defensive to a house,

\footnotetext{
25 May (2017). The website with this speech also includes a text of the speech in German.

26 Young (1998), p. 1.

27 For an insightful reading, see Knapp (2002), chapter 3 .
} 
Against the envy of less happier lands,

This blessèd plot, this earth, this realm, this England....28

No one would deny that this is stirring poetry, but who delivers the lines and in what set of circumstances? They come in Act II, scene i, from the Duke of Lancaster, John of Gaunt, ${ }^{29}$ uncle to Richard II and father of Henry Bolingbroke (Duke of Hereford). Henry has shortly before this point been sent into exile by Richard II to avoid a bloody conflict with Thomas Mowbray (Duke of Norfolk), whom the king also banishes. Although Richard shortens Bolingbroke's term of exile on appeal from Gaunt, Gaunt knows he will not live to see his son's return. Indeed the stage directions for the scene in which he delivers the memorable speech read: "Enter John of Gaunt sick". The speech covers $3^{1}$ lines in total, and it begins in prophetic mode, directed against a bad king, foretelling, as Gaunt's death approaches, that Richard cannot continue. In fact Gaunt imagines a country consuming itself, and the speech is really uttered as a lament, providing a narrative of English decline. Soon after the lines quoted above, the speech takes a troubled turn:

This land of such dear souls, this dear, dear land,

Dear for her reputation through the world, Is now leased out - I die pronouncing it Like to a tenement or pelting ${ }^{30}$ farm: England, bound in with the triumphant sea Whose rocky shore beats back the envious siege Of wat'ry Neptune, is now bound in with shame, With inky blots and rotten parchment bonds.

That England that was wont to conquer others Hath made a shameful conquest of itself. Ah, would the scandal vanish with my life, How happy then were my ensuing death! ${ }^{31}$

28 Shakespeare (2016), 2.1. 1l. 40-50.

29 Gaunt's name derives from his birth in Ghent, at St. Bravo's Abbey. His complex Continental ties include the fact that his mother was Philippa of Hainault (his father was Edward III) and he was named for John, duke of Brabant, an ally in the Low Countries of his father. Gaunt's second marriage to the exiled daughter of the murdered Pedro I of Castile gave him a claim to the Castilian crown which he asserted, adopting the royal title of King of Castile and León. See Walker (2004).

30 Worthless, paltry.

$3^{1} \quad$ Shakespeare (2016), 2.1.57-68. 
England has become a tax farm (confirmed in the prior scene, Act 1, scene iv, in fact, by Richard himself). It has lost its freedom, or sovereignty if you like, as a result of legal agreements that have bound it. The country, defensively sealed off by the sea, has paradoxically conquered itself. In short, the sense of England as something glorious is uttered in the midst of the fear of inevitable decline. Something of the recuperative desire among Brexiteers to resume a relationship with the commonwealth after the departure from Europe seems to echo in Gaunt's lament.

Richard II includes the exile of two figures, Bolingbroke and Mowbray, as I mentioned. When Mowbray confronts this prospect, he delivers a rather striking speech about the implications he will confront in terms of language. The way he describes his fate is instructive for a number of reasons:

The language I have learnt these forty years, My native English, now I must forego, And now my tongue's use is to me no more Than an unstringèd viol or a harp, Or like a cunning instrument cased up, Or, being open, put into his hands That knows no touch to tune the harmony. Within my mouth you have engaoled my tongue, Doubly portcullised with my teeth and lips, And dull unfeeling barren ignorance

Is made my gaoler to attend on me. I am too old to fawn upon a nurse, Too far in years to be a pupil now. What is thy sentence then but speechless death, Which robs my tongue from breathing native breath? ${ }^{32}$

Perhaps one of the hidden stories of Brexit, consistent with the assertion of a 'global Britain, open for business' as the solution to this political maneuver, is about the dominant position of the English language. For a traveller or exile in Shakespeare's time (let alone Richard II's), English was a language that would have done little to facilitate communication on the Continent. Indeed the purpose of travel was precisely to acquire knowledge of foreign tongues, especially French and Italian. If the English language did not now occupy a dominant position, would the outcome of the referendum on EU membership

Shakespeare (2016), 1.3.153-67. 
have come out differently? Had it remained a minority language, forcing 'Britons' either to travel to acquire fluency or to study languages properly in school to gain proficiency, they might have remained more attuned to the European prospect.

The same thought returns us to a twist on Defoe's poetic invocation of mixture: English was not the only language spoken on the 'sceptred isle' either in his time or Shakespeare's. For that matter, English itself is a combination of Anglo-Saxon, Latin and French, so it is a polyglot product. What is hybrid is sold as unitary. It is worth noting that in Richard II Bolingbroke responds to his exile as "enforcèd pilgrimage", which his father regards as a foil that will set off "The precious jewel of thy home return". ${ }^{33}$ Bolingbroke promises to remain "Though banished, yet a true-born Englishman". ${ }^{34}$

In Shakespeare's history cycle the triumphant moment comes in Henry $V$ with its staging of the famous victory at Agincourt and the assertion of Henry's dynastic claim to France. This play makes the composite nature of the monarchy more conspicuous, not least with the cameo of Macmorris with his stage Irish speech and famous query "What ish my nation?", but more obviously with the comic presence of the Welsh, notably in the figure of Llewellyn (Fluellen), with whom Henry acknowledges kinship as descendant of a Welsh family himself. ${ }^{35}$ What is more, the play draws attention to the problem of the Scots. They will take any opportunity to stir up trouble and invade if the English dally in Continental wars. For this reason, some of the nobility and their forces must remain behind, leaving Henry outnumbered against the French, although of course he proves more glorious in victory over them as a result. At least the Scots merit respect in this regard; the other 'nations' of the realm are appropriated as comic supporting parts in an English drama of self-realisation. This is so despite the fact that Ireland is promised to Princess Catherine of France as part of her enticement to marry the victorious English sovereign. ${ }^{36}$

Henry $V$ turns on kinship registered as hostility in rival claims for patrimony. In the peace negotiations at the close of the play (Act V, scene ii) the king of France is addressed as brother and his wife as sister. Yet there is still an elaborate playing out of old opacities in the wooing scene between Henry and Catherine (his future Queen Consort) where neither has fluency in the other's language. As Henry remarks - speaking prose, interestingly, in this scene: "It is as easy for me, Kate, to conquer the kingdom as to speak so much more

\footnotetext{
33 Shakespeare (2016), 1.3.253, 256.

34 Shakespeare (2016), 1.3.272.

35 Shakespeare (2016), 4.7.89.

${ }_{3} 6$ See Shakespeare (2016), 5.2.210.
} 
French. I shall never more move thee in French, unless it be to laugh at me". ${ }^{37}$ Most of this is set up to the disadvantage of Catherine, to English ears at least, though as part of the comic closure the scene is played affectionately rather than as rough wooing: "Your majesté 'ave faux French enough to deceive de most sage demoiselle dat is en France". ${ }^{38}$ The paradox is that the audience must understand some French to get the joke. What Henry proposes is an alliance in which their hybrid prodigy will fight a common foe: "thou must therefore needs prove a good soldier-breeder: shall not thou and I, between Saint Denis and Saint George, compound a boy, half-French, half-English, that shall go to Constantinople and take the Turk by the beard?"39

The prospect of engaging in new adventures in conquest promises to knit together old oppositions. Something of the same hope, in a secularised vein, seems to inspire the questing for new trade deals in the post-Brexit agenda.

But the promised triumphs may be as vanishing as Henry's glory. It is worth remembering how the next play in Shakespeare's historical sequence (Henry $V I$ ) opens - with the funeral march for Henry V, his demise coming quickly after his celebrated victories. News of setbacks in France quickly mounts up, punctuated by a bold address from a messenger reporting on military misfortunes in the country:

Awake, awake, English nobility!

Let not sloth dim your honours new-begot!

Cropped are the flower-de-luces in your arms;

Of England's coat, one half is cut away. ${ }^{40}$

The capacity of Shakespeare to offer us plots that allegorise the present is undoubtedly rich. Cymbeline, his historical romance of resistance in Roman Britain, represents a particularly noteworthy drama from this point of view. King Cymbeline is a vassal to Rome. His two sons having been stolen away in their childhood, he is left only with a beautiful daughter, Innogen. She suffers at the hands of a plotting step-mother, Cymbeline's queen, who seeks to wed Innogen to her loathsome son Cloten, despite the fact that she has already married Posthumus Leonatus (without her father's consent). Disputes with Rome provide an important backdrop to the romance action. Cymbeline refuses to pay the tribute he owes to Rome, rejecting the appeals of the Roman

\footnotetext{
37 Shakespeare (2016), 5.2.166-8.

$3^{8}$ Shakespeare (2016), 5.2.194-5.

39 Shakespeare (2016), 5.2.183-6.

40 Shakespeare (2016), 1.1.78-81.
} 
ambassador who invokes the prospect of a new invasion in retaliation. Some complicated plot twists lead Innogen to Milford Haven, where it transpires that her lost brothers have been raised (in ignorance of their true paternity). Their courage shines forth as they fight against the Roman forces. Innogen, disguised as a boy, Fidele, is held by the Romans, who have been joined by her husband. The Britons overcome their opponents, and Cymbeline contemplates executing his adversaries, but he pauses when Fidele comes to his attention. Romance resolution ensues, with Cymbeline's valiant sons restored to him, and Innogen to her Posthumus, allowing comedy to be rescued from tragedy.

And what of the Romans? Cymbeline makes peace with them, blaming his decision to refuse their demands on his late queen (who dies acknowledging her plots against him and Innogen). The king remarks:

Although the victor, we submit to Caesar,
And to the Roman empire, promising
To pay our wonted tribute, from the which
We were dissuaded by our wicked Queen. ${ }^{41}$

Thus the political situation, in spite of all the intricate skirmishing, ends up where it began. Will this, one wonders, prove to be the case with the UK's ostensible departure from the EU? Representatives of the Remain campaign must hope for the predictive power of the Soothsayer's speech, the penultimate one in the play. He states:

For the Roman eagle

From south to west on wing soaring aloft

Lessened herself, and in the beams o'th' sun

So vanished; which foreshadowed our princely eagle,

Th'imperial Caesar, should again unite

His favour with the radiant Cymbeline. ${ }^{42}$

Cymbeline himself endorses this conclusion in the final lines, proclaiming: "Let / A Roman and a British ensign wave / Friendly together", ${ }^{33}$ before proposing a march through London. The balance that Constance Jordan finds in the ending of Cymbeline: "At the play's conclusion Britain remains a vassal state of Rome, but she retains the fundamental liberties she would have were she

\footnotetext{
41 Shakespeare (2017), 5.5.459-62.

42 Shakespeare (2017), 5.5.469-74.

43 Shakespeare (2017), 5.5.478-8o.
} 
independent of Rome, ${ }^{34}$ might express the hopes of Remainers or those who seek the softest of Brexits with as close an alliance with the EU as possible. Advocates for Brexit, meanwhile, harp on about the vassal state position of Britain in the EU and, in their more extreme moments, insist on withholding the $£_{39}$ billion divorce bill, refusing this 'tribute' to a foreign overlord.

\section{Coda: Churchillian Contradictions}

The contradictions in British identity and the relationship to Europe have persisted over time, constituting an ongoing legacy. The aftermath of World War II and the efforts to create lasting peace through economic cooperation deepened the conflict over separateness or integration for British politicians rather than resolving it. Winston Churchill embodied these contradictory impulses. He remains an important figure since, as Boris Johnson remarks in a selfserving biography, "thrusting young Tories - and especially males - will regard Winston Churchill as a sort of divinity." 45 Yet Johnson is forced to acknowledge that Churchill also occupies this deified role in a European context, as "one of the presiding divinities of the European Union". ${ }^{46}$ Churchill articulated a view in favour of a United States of Europe as early as 1930 and endorsed it again in a speech in Zurich in September 1946 supporting the creation of what became the Council of Europe. ${ }^{47}$ Yet Johnson is right to suggest this is not the whole of the story. Hugo Young, from a very different political perspective, affirms that "most of Churchill's blueprints, however, placed Britain/England outside the European construct." 48 The country would somehow stand apart while encouraging European integration, ${ }^{49}$ moving in an orbit determined by commitments to the Empire and Commonwealth, and a vision, as Churchill saw

\footnotetext{
44 Jordan (1997), p. 69. For a valuable study of the play, see King (2005).

45 Johnson (2014), p. 31.

46 Johnson (2014), p. 290.

47 For Churchill's supportive speeches and contributions to the Council, see archived sources on the Council website https://www.coe.int/en/web/documents-records-ari chives-information/winston-churchill-and-the-ce.

48 Young (1998), p. 13.

49 In a speech to the Commons (as leader of the opposition) on 27 June 1950, Churchill stated: "I cannot conceive that Britain would be an ordinary member of a Federal Union limited to Europe in any period which can at present be foreseen [...]. Although a hardand-fast concrete federal constitution for Europe is not within the scope of practical affairs, we should help, sponsor and aid in every possible way the movement towards European unity. We should seek steadfastly for means to become intimately associated with it." Quoted in Johnson (2014), p. 293.
} 
it, of the English speaking peoples in alliance (including, above all, the US). Britain's role as a world power would continue.

In these discussions, Ireland remained vestigial. During the referendum campaign the country was equally ignored. Northern Ireland and scope for a return to violence in the event of a hard border scarcely figured in public debate (Tony Blair and John Major gave a joint address in Derry two weeks before the vote, warning against a Leave outcome and appealing to the undecided, but their advice was ignored). The blithe dismissal of this concern by many advocates of Brexit is a shocking reminder of the low priority attached to Irish concerns.

What of Churchill himself? As a liberal he supported Home Rule, writing in 1911 that

It must always be a guiding star of British statesmanship not only to federate the Empire, but to draw nearer in bonds of friendship and association to the United States. The road to the unity of the English-speaking races is no doubt a long one, and we cannot see the end of it. But it is an open road, and an Irish parliament, loyal to the Crown, and free to make the best of the Emerald Isle, is assuredly the first milestone upon it. ${ }^{50}$

This invocation draws attention to the line of thinking developed in Churchill's four-volume History of the English-Speaking Peoples (1956-58). Ireland does not feature in any prominent way in the history, which is noteworthy in itself, but the country does intrude in the nineteenth-century narrative. Recounting the struggles for Home Rule, he remarks that "it must not be supposed that the Irish picture can be seen from Britain entirely in black and white."51 Describing from earlier in the century the cause of Daniel O'Connell and Catholic Emancipation, Churchill notes a speech in the House of Lords by Wellington (whose Irish origins he points out) and the stark words Wellington spoke in relation to the potential for civil war:

I am one of those who have probably passed a longer period of my life engaged in war than most men, and principally in civil war; and I must say this, that if I could avoid by any sacrifice whatever even one month of civil war in the country to which I was attached I would sacrifice my life in order to do it. ${ }^{52}$

5 Q Quoted in Roberts (2018), p. 163.

$5^{1} \quad$ Churchill (1956-58), vol. 4, p. 27 O.

$5^{2} \quad$ Churchill (1956-58), vol. 4, p. 3 о. 
The warnings about Ireland are there, in other words, even in Tory sources.

Churchill ended his history on a note of uncertainty:

Here is set out a long story of the English-Speaking Peoples. They are now to become Allies in terrible but victorious wars. And that is not the end. Another phase looms before us, in which alliance will once more be tested and in which its formidable virtues may be to preserve Peace and Freedom. The future is unknowable, but the past should give us hope. Nor should we now seek to define precisely the exact terms of ultimate union. ${ }^{53}$

Brexiteers have lost contact with the post-war inspiration to unify Europe, opposing the strategy of creating supranational institutions in order to interlock the fate of nations in the European continent. ${ }^{54}$ Meanwhile, they look to old alliances, largely Anglophone in the first instance - with America and the Commonwealth (i.e. English-speaking peoples) - to mitigate the consequences of departure.

Taking an early modern perspective on the longue durée of Brexit reveals not only the durability of a sense of separateness but also the tensions and inconsistencies within it. When Linda Colley reviewed the emergence of a British identity in her 1992 book Britons. Forging the Nation 1707-1837, she observed that the driving forces leading to this artificial construct (protracted war with France; Protestant religious difference; and the fight to retain and expand an empire) had disappeared in the late twentieth-century moment in which she wrote: not only in the loss of overseas territories but in Protestant religious attachments. She saw the appearance of more assertive forms of Welsh, Scottish and even English nationalism as responses to "a broader loss of national, in the sense of British, identity". In a remark that now reads as prophesy, she commented:

Indeed, now that it is part of the European Economic Community, Great Britain can no longer comfortably define itself against the European powers at all. Whether it likes it or not, it is fast becoming part of an increasingly federal Europe, though the agonies of British politicians and voters of all partisan persuasions so plainly experienced in coming to terms with Brussels and its dictates show just how rooted the perception of Continental Europe as the Other still is. ${ }^{55}$

53 Churchill (1956-58), vol. 4, p. 304.

54 For an account, see O'Rourke (2019).

55 Colley (1992), p. 6. 


\section{Bibliography}

Black, Jeremy (2019). Britain and Europe. A Short History (London: Hurst \& Co.).

Borsing, Christopher (2017). Daniel Defoe and the Representation of Personal Identity (Abingdon: Routledge).

Bradshaw, Brendan, John Morrill (eds) (1996). The British Problem, c. 1534-1707. State Formation in the Atlantic Archipelago (Houndmills, Basingstoke: Macmillan).

Bradshaw, Brendan, Peter Roberts (eds) (1998). British Consciousness and Identity. The Making of Britain 1533-1707 (Cambridge: Cambridge University Press).

Churchill, Winston (1956-58). A History of the English-Speaking Peoples, 4 vols (London: Cassell).

Colley, Linda (1992). Britons. Forging the Nation 1707-1837 (New Haven: Yale University Press).

Connelly, Tony (2018). Brexit and Ireland. The Dangers, the Opportunities, and the Inside Story of the Irish Response. Updated edn. (London: Penguin Books).

Cottret, Bernard (2019). Les Tudors. La démesure et la gloire, 1485-1603 (Paris: Perrin).

[Defoe, Daniel] (2003), 'The True-Born Englishman. A Satyr', in Satire, Fantasy and Writings on the Supernatural by Daniel Defoe, gen. eds W. R. Owens and P. N. Furbank, vol. 1, The True-Born Englishman and Other Poems, ed. by W. R. Owens (London: Pickering \& Chatto).

Defoe, Daniel (200o). Robinson Crusoe, ed. by Thomas Keymer (Oxford: Oxford University Press).

Dickens, A. G. ([1964] 1989). The English Reformation. 2nd edn (London: B. T. Batsford). Haigh, Christopher (1993). English Reformations. Religion, Politics, and Society under the Tudors (Oxford: Clarendon Press).

Helgerson, Richard (1992). Forms of Nationhood. The Elizabethan Writing of England (Chicago: University of Chicago Press).

Heuser, Beatrice (2019). Brexit in History. Sovereignty or a European Union? (London: Hurst \& Co.).

Johnson, Boris (2014). The Churchill Factor. How One Man Made History (London: Hodder \& Stoughton).

Jordan, Constance (1997). Shakespeare's Monarchies. Ruler and Subject in the Romances (Ithaca: Cornell University Press).

Joyce, James (2000). Occasional, Critical, and Political Writing, ed. by Kevin Barry (Oxford: Oxford University Press).

Kerrigan, John (2008). Archipelagic English. Literature, History, and Politics 1603-1707 (Oxford: Oxford University Press).

Knapp, Jeffrey (2002). Shakespeare's Tribe. Church, Nation, and Theater in Renaissance England (Chicago: University of Chicago Press). 
King, Ros (2005). Cymbeline. Constructions of Britain (Aldershot: Ashgate, 2005).

MacCulloch, Diarmaid (2016). All Things Made New. Writings on the Reformation (London: Penguin).

Marshall, Peter (2017). Heretics and Believers. A History of the English Reformation (New Haven: Yale University Press).

Mason, Roger A. (ed.) (1994). Scots and Britons. Scottish Political Thought and the Union of 1603 (Cambridge: Cambridge University Press).

Mason, Roger A. (2004). 'Scotland, Elizabethan England and the Idea of Britain', Transactions of the Royal Historical Society, 14, pp. 279-293.

May, Theresa (2017). 'ANew Era of Cooperation and Partnership between the UK and the EU.' Speech delivered 22 September in Florence at https://www.gov.uk/government/ speeches/pms-florence-speech-a-new-era-of-cooperation-and-partnership-betweenthe-uk-and-the-eu [accessed 17.4.2019].

O'Rourke, Kevin (2019). A Short History of Brexit. From Brentry to Backstop (London: Pelican Books). First published 2018 as Une brève histoire du Brexit. Nous sommes tous concernés, trans. Christophe Jaquet (Paris: Odile Jacob).

O’Toole, Fintan (2018). Heroic Failure. Brexit and the Politics of Pain (London: Head of Zeus).

Roberts, Andrew (2018). Churchill. Walking with Destiny (London: Allen Lane).

Robertson, John (ed.) (1995). A Union for Empire. Political Thought and the British Union of 1707 (Cambridge: Cambridge University Press).

Sassen, Saskia (1996). Losing Control? Sovereignty in an Age of Globalization (New York: Columbia University Press).

Sassen, Saskia (2008). Territory, Authority, Rights. From Medieval to Global Assemblages. Updated edn. (Princeton: Princeton University Press).

Schmidgen, Wolfram (2013). Exquisite Mixture. The Virtues of Impurity in Early Modern England (Philadelphia: University of Pennsylvania Press).

Shakespeare, William (2016). 'Richard II', in The Complete Works. Modern Critical Edition, ed. by Gary Taylor, John Jowett, Terri Bourus, Gabriel Egan (Oxford: Oxford University Press).

Shakespeare, William (2016). 'Henry V', in The Complete Works. Modern Critical Edition, ed. by Gary Taylor, John Jowett, Terri Bourus, Gabriel Egan (Oxford: Oxford University Press).

Shakespeare, William (2016). 'Henry VI', in The Complete Works. Modern Critical Edition, ed. by Gary Taylor, John Jowett, Terri Bourus, Gabriel Egan (Oxford: Oxford University Press).

Shakespeare, William (2017). Cymbeline, ed. by Valerie Wayne (London: Bloomsbury). Shipman, Tim (2017). All Out War. The Full Story of Brexit. Rev. edn. (London: William Collins). 
Walker, Simon (2004). 'John [John of Gaunt], duke of Aquitaine and duke of Lancaster, styled king of Castile and León (1340-1399)', in Oxford Dictionary of National Biography, ed. by H. C. G. Matthew, Brian Harrison (Oxford: Oxford University Press), vol. 3०. pp. 174-183.

Young, Hugo (1998). This Blessed Plot. Britain and Europe from Churchill to Blair (London: Macmillan). 